The following paper is a post-print (final draft post-refereeing) of:

Johan Schimanski and Stephen Wolfe. "Cultural Production and Negotiation of Borders: Introduction to the Dossier." Journal of Borderlands Studies 25.1 (2010): 39-49.

The published article may be accessed at http:/ / dx.doi.org/10.1080/08865655.2010.9695749

Other articles in the dossier may be accessed at http:// www.tandfonline.com/toc/rjbs20/25/1

Access to the published version may require subscription.

N.B. When citing this work, cite the original published paper. 


\section{CULTURAL PRODUCTION AND NEGOTIATION OF BORDERS: INTRODUCTION TO THE DOSSIER}

Guest-editors: Johan Schimanski and Stephen Wolfe

\section{Abstract}

The cultural production of borders can be as read as referring to part of the economy, as an aesthetic site of creativity and border negotiation, and a cultural factor in the bordering process. The need to understand these cultural dimensions of borders and borderlands has lead to interdisciplinary interest in narratives, aesthetic forms, and cultural memory. Border poetics and related forms of spatial poetics can provide fruitful approaches to specific literary texts, films and other artworks, as well as to bordering in general. This special dossier for the Journal of Borderlands Studies presents papers from the 2008 ABS European conference in Kirkenes, which had "Cultural Production and Negotiation of Borders" as its theme and which brought together a wide range of researchers from both the social sciences and the humanities, raising questions about the role of culture in borderlands and also focusing on borders in Sub-Arctic Europe. The following selection of papers addresses films, poetry, novels and cultural heritage connected to specific topographical borderlands.

\section{Cultural production and negotiation}

As philosopher Jacques Derrida reminds us, the word culture derives from a word having to do with farming. One of the founding figures of cultural studies, Raymond Williams, goes a step further when he tells us that in English the word's development is related to that of a similar word, coulter, meaning a ploughshare (Williams 1976, 77); an implement used to divide the earth. ${ }^{1}$ Both Derrida and Williams were sceptical about a unitary conception of culture; Derrida specifically asks us to shift our focus to a conception of culture based around difference, division and borders (Derrida 1992, 7-11). The image of agricultural production through ploughing is however particularly apt in a description of a world of culture(s) often criss-crossed by and criss-crosing very material borders and borderlands. It appears that culture thrives in dialogue 
with these borderlands, as the current crop of films, literary texts and artworks dealing with borderlands shows.

This is our first argument in making this special dossier for the Journal of Borderlands Studies: that borderlands are places of cultural production, and that in a very economical sense, borderlands can be the origins of many different forms of culture. This also goes for culture produced in the national or imperial metropoles, which may also use the border as a motif or metaphor. This is a reading of cultural production as a quantifiable form of capital at the intersection of art, media and society.

Our second argument is that in order to understand how this works, we must read the concept of cultural production not just as the production of culture, but also as production through culture. Culture can be a creative and performative force in the activity of bordering; it is asite of creation, also in the context of borderlands. People engaged in cultural production can negotiate borders by providing new visions of what they may be, or even of what borders should not or cannot be. Their cultural and aesthetic practices can disrupt expectations of what borders are, through the creation of imagined and imaginary borderlands.

Alongside these economical and what we would designate as aesthetic understandings of the term cultural production, there is of course a third, more general understanding gradually gaining ground within border studies, and this is that borders are not only the products of political conflict and negotiation, but are also determined by cultural factors. Within a more constructivist paradigm, borders are seen as cultural constructs generated, circulated, and interpreted within various forms of discourse, even though they often have very physical, material or violent effects. Our claim here in putting together this dossier with its strong focus on film, literature and the heritage industry is that one specific level of discourse, the aesthetic, has a special role to play in the production and negotiation of borders.

\section{Constructing border aesthetics and border poetics}

Borders are a well-established field of study in the social sciences, in particular 
within border or borderlands studies in geography and related fields. Recently, social and political geographers working with topographical borders have increasingly been calling for cultural and narrative perspectives on the way in which borders are perceived by state actors, borderland populations, and border crossers such as migrants (Newman 2006). More and more social scientists working within borders studies are using words like "story" (e.g. Strüver 2005, 2003). This tendency is part of an increased emphasis on discourse within the frame of a "post-modernist" paradigm of border studies (Berg and Houtum 2003; Kolossov 2006; Paasi 2005a, b). In literary and cultural studies, but also in sociology, the border concept is often used for more symbolic types of border, such as the borders between cultures, genders or classes. Such symbolic borders contain within them a spatial dimension; they are manifested as spatial borders either within the real, topographical world, or within a mental map, an imaginary geography (Said 1991) or a more intimate topology of, for instance, the body (Benthien 2002; Christensen 1992).

The origin of this attempt to articulate the border as both topographical and symbolic is to be found in sociologist Georg Simmel's work on the border, first published in 1903, where he famously argues that ' $[\mathrm{t}$ ] he boundary is not a spatial fact with sociological consequences, buta sociological fact that forms itself spatially' (Simmel 1997: 142). Svend Erik Larsen (2007)has used this idea of spatial form or manifestation as an argument that borders are essentially aesthetic as well as symbolic phenomena. Borders are thus constituted and expressed on the plane of the senses (as in the original, broader meaning of the word aesthetic), as signs, or within a more deconstructive paradigm, as traces (cf. Görling 2007).

Taking these different kinds of border, topographic and symbolic, together, one may trace a complex circulation of the border concept from one register to another. Any one of the registers - national territory, cultural difference, gender, and so on - can be mapped onto one of the other registers, in allegorical transfers of meaning (Schimanski and Wolfe 2007). It is this kind of circulation which constitutes the historicity of the border concept, allowing the border concept to change and develop in different cultural and historical contexts. Taking territorial borders as a departure point, feudal territorial borders 
were quite different from those of modern nation states, being conceived of as wildernesses rather than as dividing lines (Warnke 1994); global borders towards the end of the $19^{\text {th }}$ Century were formed around colonial zones based on a racial differentiation between the European self and non-European others which has become increasingly temporalized with the introduction of theories of evolution (Frank 2006); afterthe First World War, the dissolution of empires and the Wilson doctrine caused territories and borders in Central and Eastern Europe to become increasingly multi-layered and fragmented (Robinson 2007); today we are living with discourses of globalization and hybridity which have paradoxically created both an illusion of a "borderless world" and a world in which bordershave multiplied as they are folded into nations, in the form of refugee camps, detention centres, urban enclaves, walled communities, and tourist spaces. They are even folded into the identities of individual subjects.

Such a historical sequence of border concepts in both topographical and symbolic registers cannot, however, be taken only at face value. New borders overwrite older borders. The landscape is based either on the repetition or negation of a previous landscape. The border or the border zone is a place of memory, of remembering or forgetting, to the extent that it is perceived as a place. As a place, it is made up of traces of previous borders and bordering activities. Border crossing can also involve acts of remembering or forgetting. Typical cases of the articulation of borders through memory would be that of a border-crosser who brings with her a souvenir to / from the other side (Castillo 2007), or of the use of historical photos in analyzing memories of erased borders (Meinhof 2002). Borderings involving state and legal power are ultimately built on the idea of the trace, as borders are made legitimate by an appeal to a precedent that is to be found in the form of evidence, be it in archives, maps, folklore, storytelling, old markers or even the physical landscape itself.

Representations of borders in novels, short stories, poems, films, plays, videos, artworks, museums and the like are very often traces in the sense that they are historical. They can be narrated/enunciated in the past, and they can be narrated as being the past. Various kindsof aesthetic narratives and figurations can function as remembering practices that bring past historical layers of border spaces and border concepts to light. Just one example would be Sophie Calle's 
artwork based around the ritual eruv border and its use in present-day Jerusalem (Vest Hansen 2007). Each border carries within it an archaeology of previous borders, and this archaeology can play an active part in the renegotiation of borders if it is opened to new border concepts or used to construct a deconventionalizing perspective. Thus the aesthetic dimension emphasizes the affective dimensions in our reactions to the border and ethical considerations of the type already examined in psychoanalysis (Lichtenberg-Ettinger 1994), existentialist philosophy (Jaspers 1956), international relations (Williams 2006), and political philosophy (Agamben 1998, 2005).

The term border poetics has been suggested by various scholars and writers during the last fifteen years (Görner 1999; Karahasan and Jaroschka 2003; Schimanski 1996; Tygstrup 2000; Sidaway 2005). In broad terms, it is the study of how territorial borders are given form through narrative and symbolic presentations. ${ }^{2}$ An initial specificity is called for in face of the wide use of such a highly applicable term as border - along with boundary, threshold, limit, crossing and transgression - in many different contexts. Several studies have suggested the usefulness of such an approach in the practice of literary analysis, without necessarily using the term border poetics (Aguirre 2006; Cixous 1993; Ette 2001; Henderson 1995; Hicks 1991; Koschorke 1990; Lamping 2001; Wolfe 2006; Liet 2008). Some (Moretti 1998; Schimanski 2001, 2003; Bal 2006) have specifically referred to an ongoing discussion of national spaces as rhetorically formed constructs (Anderson 1991, Bhabha 1994, 139-170) and to postcolonially inflected discussions of hybrid identities and third spaces (Bhabha 1994, Anzaldúa 1991). Other work, including that based around research projects at Potchefstroom and Madrid, has focused on the relationship between liminality and narrative, a powerful connection which stresses the needto think through the temporal aspects of border crossings (Benito and Manzanas 2006; Viljoen and Merwe 2007).

Larsen, mentioned above, argues that borders have a key role to play in the discussion of the arts as a central part of the production of culture (Larsen 2007). He is however aware that aesthetic objects within the field of culture are themselves structured by various kinds of borders. The aesthetic manifestations of borders are likewise bordered in their medial manifestations, either in their 
framing, in their compositional divisions or in the hermeneutic relationship between perceiver and object. More specifically then, border poetics is an investigation of a specific element (the border) in the relationship between spaces represented on the one hand and the spaces of representation (e.g. the literary text as a spatial object) on the other (cf. Bakhtin 1981, 252-253; Schimanski 2006). Bordering thus not only involves symbolic and topographical registers, but also textual or medial ones. It is significant that one important contribution to the theory of borders in general takes place in an essay on textual genre (Derrida 1980), and Simmel himself likens the border to the frame of the artwork (Simmel 1997, 141). Representations of topographical borders can also be associated with certain genres and even specific rhetorical tropes. It has been claimed, for instance, that borders are a site of raised figurality (Moretti 1998, 45-47).

In recent discussions in the humanities and cultural theory, the rhetorical and narrative construction of borders and borderlands has centred around terms such as contact zones (Pratt 1992), spaces of negotiation (Bhabha 1994, Boer 2006) and rhizomes (Deleuze and Guattari 1987). Borders, and border subjects' experiences of them, are increasingly seen as sets of interlinked processes or formations through which traces are sedimented in border narratives and within a mental and physical landscape. Border poetics as we envision it also belongs properly to the study of a poetics of space in general, already well established in literary and cultural theory (Bachelard 1994; Bakhtin 1981, 259-422; Frank 1963; Lotman 1977; Miller 1995; Moretti 1998, 2005; Tygstrup 2000; Friedman 2005). This poetics of space is in turn related to the wider field of spatial studies in the human sciences, underpinned by the work of social scientists and cultural theorists such as Certeau (1984), Lefebvre (1991), Virilio (1986), Massey (1994, 2005) and Soja (1989).

In the last ten years, there has been a realization that changes in the borders that have traditionally fenced the fields and practices of the social sciences and the humanities are connected to changes in the nation state, global shifts in migration, post-colonial wars, struggles to create new nations, and the creation and renewal of multinational institutions. In the humanities and the social sciences these changes have produced an interdisciplinary terrain often focusing on refigurations and crossings of those boundaries which have been 
central and critically important to the creation of border studies itself.

Increasingly, scholars emphasize the theory and practice of working in the "space between" as they focus on the processes of negotiating the border within the intersections or folds which have been recently exposed in bordering processes themselves.

\section{The 2008 ABS European Conference in Kirkenes}

The articles we are presenting were all first given as papers at the 2009 European Conference of the Association of Borderlands Studies, held in Kirkenes in Northern Norway, September 11-13, on the borders of the Arctic and in the Finnish-Kven-Norwegian-Russian-Sámi borderland. The conference was arranged by Border Poetics research group (http:/ / uit.no/borderpoetics) at the University of Tromsø, in close cooperation with the History Department and theCEPIN (Citizenship, Encounters and Place Enactment in the North) research school there, the Petrozavodsk State University and vitally, the Barents Institute in Kirkenes itself. Various policy and cultural groups were also involved, such as the Kirkenes cultural production outfit Pikene på broen, the Norwegian Barents Secretariat, the Borderlands Museum, the Akademisk Kvarter bookshop, the Pasvikturist tourist agency and Samovarteatret.

The theme of the conference was a wide one: the "Cultural Production and Negotiation of Borders". This theme was intended as an acknowledgement of the increasing focus which has been given recently by geographers, anthropologists and historians to the role of cultural production and negotiation in social and territorial bordering processes. The ongoing spate of movies, documentaries, art projects, novels, websites, festivals and tourist attractions concerning borders has given this aspect of bordering renewed topicality and economic importance, and has attracted research both in the humanities and in the social sciences. The stories such cultural practices and artefacts tell, and the images they project, give extra weight to questions about the location of borders and of border populations. In some cases, the border itself - a wall, a fence or a bridge $^{3}$ - becomes a cultural icon of great significance in the media and in everyday discourse. In a world of mobilities and securities, the outer peripheries 
of states are clearlylinked to their hybridized urban landscapes and even to the bodies of immigrants and other border-crossers themselves. The cultural negotiation of contested borders is a crucial element of ongoing problems of security, freedom of movement, economic differentials, trafficking, fearof the other, etc.; it also promises the possibility of a creative refiguring of borders and cultural border zones into economically and symbolically productive sites of dialogue, crossing, hybridity and performance. All these phenomena are the product of historical processes and take placein a shifting historical landscape which both creates a framework for and is formed by cultural practices. Borders are also a central metaphor in cultural theory, and there is need to reflect over the reasons for this.

The conference was thus envisaged as an interdisciplinary conference which would cross the academic divide between "border studies" in the social sciences and "border theory" / "border poetics" in the humanities. It aimed to examine the ways cultural practices use discursive and semiotic strategies in order to imagine and negotiate the border in its social and historical context and to further our understanding of the role of culture in subjective interactions with the border by border crossers and by border zone dwellers. While focusing on bottom-up perspectives, papers raised questions about the need for localized solutions in top-down policy-making, actualised with the increasing economic significance of cultural production and consumption. They asked who initiates and who benefits from such cultural practices, and what their symbolic effects are for social conditions. They aimed to place cultural processes of bordering in historical contexts and show the role of cultural memory in the formation of borderscapes. They traced the transferability of the border concept to questions of identity, subjectivity and medial exposition as facilitated by cultural practices.

A special focus of the conference was the region in which it is set: the Norwegian-Russian- Finnish-Sámi borderland and the wider contexts of the North Calotte, Barents and Arctic regions. The Arctic is an area in which the borders of the environment and energy production are being changed and are changing the geographical, historical, imaginative sense of place and space. This is a transborder region of a layered, complex border history (cf. Jackson and Nielsen 2005), of pressing social and environmental problems and possibilities 
involving many different cultural identities and ways of life, and of high importance today as a political and cultural hotpoint of "Western"-Russian relations within the Arctic and Sub-Arctic context. Kirkenes, an old mining town, lies at a point where the interests of many nations and indigenous/minority groups meet, and has been a place of social, economic, environmental, military and cultural confrontation; now it is a site of economic and cultural creativity involving the aspirations and self-narratives of local, national and global elites in an atmosphere of hybridity (Viken, Granås, and Nyseth 2008). It is centrally placed in relationship to the ongoing construction and contestation of territorial and symbolic borders in the Arctic sea against a background of rapid economic development of oil and gas resources. The conference also included a final summing- up panel made up of scholars working from different perspectives on the Norwegian-Russian- Sámi-Kven-Finnish borderscape.

\section{The articles}

Careful deliberation has gone into choosing papers for this dossier. The conference attracted 69 registered participants including geographers, literary scholars, historians, philosophers, ecologists, library scientists, tourism researchers, political scientists, media scientists, anthropologists, ethnologists, sociologists, economists, artists, and artistic producers. The programme included in all 48 papers, 22 of which dealt specifically with borderlands between Norway, Sweden, Finland and Russia. Many of these "northern" papers have appeared in a special issue of the Journal of Northern Studies (2009/1). Other papers, including Mieke Bal's keynote lecture, have appeared in a separate dossier, in the open-access journal Nordlit (no. 24, 2009). A conference report has appeared in the La Frontera newsletter (Schimanski and Wolfe 2009). For the Journal of Borderlands Studies we have chosen articles according to our original intention of crossing the academic divide between border studies in the social sciences and border theory or border poetics in the humanities. We have purposefully chosen papers which expose more humanistic concerns and aesthetic themes, partly written within disciplines new to the journal (cf. Pisani, Reyes, and García 2009). 
It lies in the nature of aesthetic discourses that their specific forms of intervention, production, and negotiation work through various forms of representational displacement, with the border not always being described in a directly recognizable or transparent way. These displacements include narrative, fictional, and metaphorical reinscriptions of the border. Aesthetic discourses thus make discussion of imaginary and symbolic borderlands necessary, and within a discursive approach to borders it is indeed important to acknowledge the role such displacements have to play in all formation of borders, even territorial borders. Each of the following articles is grounded in the last instance in specific geographical borderlands. We have deliberately excluded papers dealing with symbolic borders not easy to connect to actual borderlands.

We begin by highlighting an article by Timothy Saunders which challenges us to locate our contemporary concepts and diction within a broader historical trajectory. Saunders argues that central terms in the analysis of culture show their origins as spatial metaphors taken from Latin, and that Virgil's poetry connects some of these terms in negotiating the Roman sense of borders and empire.

The two essays on film by Tanya Kudryavtseva and Holger Pötzsch suggest that boundaries are not to be read as lines, limits, or cuts through inhabited worlds, but are liminal spaces in themselves. Indeed, both show how cinema itself is a liminal space, implying that there is a slippage between the concrete borderlands which are represented and the borders of the medium itself. Pötzsch's article challenges us to think of war as creating a specific, highly conflictual and transitional form of borderland, which may have implications for the study of more established borders. Kudryavtseva, investigating Northern borderlands, also makes us aware of the North as a border onto a completely "other" space, at the edge of culture itself.

Kristina Aurylaite's article addresses the way novels represent the negotiation of collective and individual identities in borderlands, and thus negotiate the border as a cultural construction. Importantly, her example, centred around First Nation reservations in Canada, points to the significance of internal territorial borders in the construction and experience of national and indigenous communities. 
All these articles in some way or another touch upon the potential of artworks and cultural products to mediate the historical dimensions of borders and their layering of traces and memories. Our final article, by Maria de Fátima Amante, confronts this topic head on by examining how the heritage industry and local people use cultural memories in different, sometimes conflicting ways in the construction of identity in the Portuguese-Spanish borderlands. A disjunction is revealed between local cultural discourses and actual social conditions, manifested also in a top-down/bottom-up dynamic.

While Amante is examining a more collective form of cultural production involving many different actors, we would claim that this top-down/bottom-up dynamic is also central tothe narratives presented in literature, art and film, eminently capable of presenting the lived experience of negotiating borders. However, a culture-orientated humanities perspective, aware of the medial, discursive and aesthetic dimensions of borders, can also provide an alternative set of tools for self-reflection, critical thinking, and evaluating social change in borderlands studies. We hope through this dossier to further put cultural production on the map of border studies and to give continued momentum to a widened interdisciplinary in the field. ${ }^{4}$ We very much regret the untimely death of Tatjana Kudrjavtseva, whose essay appears in this dossier. We will miss a vibrant and valued colleague.

\section{Endnotes}

1. One can develop a whole discursive archaelogy of the border concept through etymology (Fink 1999; and see the article by Saunders in this dossier).

2 . The OED defines poetics as "[t]he creative principles informing any literary, social or cultural construction, or the theoretical study of these; a theory of form". 3. In many Turkish-German narratives, the Bosporus Bridge, connecting Europe and Asia, plays a central role (Görling 2007; McGowan 2000).

4. Some of the ideas for this introduction have been developed in discussions with other members of the Border Poetics group, and we would like to thank them along with everyone else who made the Kirkenes conference possible and successful.

\section{References}

Agamben, Giorgio. 1998. Homo Sacer: Sovereign Power and Bare Life. Trans. D. Heller-Roazen. Stanford, CA: Stanford Univ. Press. 
Agamben, Giorgio. 2005. State of Exception. Trans. K. Attell. Chicago: Univ. of Chicago Press.

Aguirre, Manuel. 2006. Liminal Terror: The Poetics of Gothic Space. The Dynamics of the Threshold: Essays on Liminal Negotiations, eds. J. Benito and A. M. Manzanas, 13-38. Madrid: Gateway Press.

Anderson, Benedict. 1991. Imagined Communities: Reflections on the Origin and Spread of Nationalism. Revised and extended ed. London: Verso.

Anzaldúa, Gloria. 1991. Borderlands: La Frontera: The New Mestiza. San Francisco: Aunt Lute Books.

Bachelard, Gaston. 1994. The Poetics of Space. Trans. M. Jolas. Boston: Beacon Press. Bakhtin, M. M. 1981. The Dialogic Imagination: Four Essays. Trans. C. Emerson and M. Holquist, ed. M. Holquist. Austin: Univ. of Texas Press.

Bal, Mieke. 2006. Meanwhile: Literature in an Expanded Field. In A Mieke Bal Reader, 443- 457. Chicago: Univ. of Chicago Press.

Benito, Jesús, and Ana Ma Manzanas. 2006. Of Walls and Words: An Introduction. The Dynamics of the Threshold: Essays on Liminal Negotiations, eds. J. Benito and A. M. Manzanas, 1-11. Madrid: Gateway Press.

Benthien, Claudia. 2002. Skin: On the Cultural Border between Self and the World. New York: Columbia Univ. Press.

Berg, Eiki, and Henk van Houtum. 2003. Prologue: A Border is Not a Border: Writing and Reading Borders in Space. Routing Borders between Territories, Discourses and Practices, eds. E. Berg and H. v. Houtum, 1-10. Aldershot: Ashgate.

Bhabha, Homi K. 1994. The Location of Culture. London: Routledge.Boer, Inge E. 2006. Uncertain Territories: Boundaries in Cultural Analysis. Edited by M. Bal, B. v. Eekelen and P. Spyer. Amsterdam: Rodopi.

Castillo, Debra A. 2007. Borders, Identities, Objects. In Border Poetics De-limited, eds. J. Schimanski and S. Wolfe, 115-48. Hannover: Wehrhahn.

Certeau, Michel de. 1984. The Practice of Everyday Life. Trans. S. F. Rendall. Berkeley, CA: Univ. of California Press.

Christensen, Christa Lykke. 1992. Kroppens grænser - streiftog på hudens overfalder. In Grænser, eds. F. Stjernfelt and A. Troelsen, 177-99. Århus: Aarhus universitetsforlag.

Cixous, Hélène. 1993. Three Steps on the Ladder of Writing. Trans. S. Cornell and S. Sellers. New York: Columbia Univ. Press.

Deleuze, Gilles, and Félix Guattari. 1987. A Thousand Plateaus: Capitalism and Schizophrenia. Minneapolis, MN: Univ. of Minnesota Press.

Derrida, Jacques. 1980. The Law of Genre. Critical Inquiry 7 (1): 55-81.

Derrida, Jacques. 1992. The Other Heading: Memories, Responses and Responsibilities. In The Other Heading: Reflections on Today's Europe. Bloomington: Indiana Univ. Press.

Ette, Ottmar. 2001. Literatur in Bewegung: Raum und Dynamik grenzüberschreitenden Schreibens in Europa und Amerika. Weilerswist: Velbrück Wissenschaft.

Fink, Hans. 1992. Om grænsers måde å være grænser på. In Grænser, eds. F. Stjernfelt and A. Troelsen, 9-30. Århus: Aarhus universitetsforlag.

Frank, Joseph. 1963. The Spatial Form in Modern Literature. In The Widening Gyre: Crisis and Mastery in Modern Literature, 3-62. New Brunswick, NJ: Rutgers Univ. Press.

Frank, Michael C. 2006. Kulturelle Einflussangst: Inszenierungen der Grenze in der 
Reiseliteratur des 19. Jahrhunderts. Bielefeld: transcript.

Friedman, Susan Stanford. 2005. Spatial Poetics and Arundhati Roy's The God of Small Things. In A Companion to Narrative Theory, eds. J. Phelan and P. J. Rabinowitz, 192-205. Malden, MA: Blackwell.

Görling, Reinhold. 2007. Topology of Borders in Turkish-German Cinema. In Border Poetics De-limited, eds. J. Schimanski and S. Wolfe, 149-62.

Hannover: Wehrhahn.

Görner, Rüdiger. 1999. 'Poetik' der Grenze. In Nachdenken über Grenzen, eds. R. Görner and S. Kirkbright, 105-18. München: Iudicium.

Henderson, Mae G. 1995. Introduction: Borders, Boundaries, and Frame(work)s. In Borders, Boundaries and Frames: Essays in Cultural Criticism and Cultural Studies, ed. M. G. Henderson, 1-30. New York: Routledge.

Hicks, D. Emily. 1991. Border Writing: The Multidimensional Text. Minneapolis: Univ. of Minnesota Press.

Jackson, Tatjana N., and Jens Petter Nielsen, eds. 2005. Russia - Norway: Physical and Symbolic Borders. Moscow: Languages of Slavonic Culture.

Jaspers, Karl. 1956. Philosophie: II: Existenzerhellung. 3. Auflage ed. Berlin: Springer. Karahasan, Dževad, and Markus Jaroschka, eds. 2003. Poetik der Grenze. Graz: Steirische Verlagsgesellschaft.

Kolossov, Vladimir. 2006. Theoretical Limology: New Analytical Approaches. Crossing the Border: Boundary Relations in a Changing Europe, ed. T. Lundén, 15-35. Huddinge: Centre for Baltic and East European Studies, Södertörn University College.

Koschorke, Albrecht. 1990. Die Geschichte des Horizonts: Grenze und Grenzüberschreitung in literarischen Landschaftsbildern. Frankfurt a. M.: Suhrkamp.

Lamping, Dieter. 2001. Über Grenzen: Eine literarische Topographie. Göttingen: Vandenhoeck \& Ruprecht.

Larsen, Svend Erik. 2007. Boundaries: Ontology, Methods, Analysis. In Border Poetics De-limited, eds. J. Schimanski and S. Wolfe, 97-113. Hannover: Wehrhahn.

Lefebvre, Henri. 1991. The Production of Space. Trans. D. Nicholson-Smith. Oxford: Blackwell.

Lichtenberg-Ettinger, Bracha. 1994. The Becoming Threshold of Matrixial Borderlines. In Travellers' Tales: Narratives of Home and Displacement, ed. G. Robertson, 38-62. London: Routledge.

Liet, Henk van der. 2008. Engendering a Memorable Place: Holger Drachmann as Travel- Writer. In The Discovery of Nineteenth-Century Scandinavia, ed. M. Wells, 192-46. Norwich: Norvik Press.

Lotman, Ju. M. 1977. The Structure of the Artistic Text. Trans. G. Lenhoff and R. Vroon. Ann Arbor: Department of Slavic Languages and Literatures University of Michigan.

Massey, Doren. 1994. Space, Place and Gender. Cambridge: Polity Press. Massey, Doreen. 2005. For Space. London: SAGE.

McGowan, Moray. 2000. 'The Bridge of the Golden Horn': Istanbul, Europe and the 'Fractured Gaze from the West' in Turkish Writing in Germany. Yearbook of European Studies 15: 53-69.

Meinhof, Ulrike H., ed. 2002. Living (with) Borders: Identity Discourses on East-West Borders in Europe. Aldershot: Ashgate. 
Miller, J. Hillis. 1995. Topographies. Stanford, CA: Stanford Univ. Press. Moretti, Franco. 1998. Atlas of the European Novel 1800-1900. London: Verso.

Moretti, Franco. 2005. Graphs, Maps, Trees: Abstract Models for a Literary History. London: Verso.

Newman, David. 2006. The Lines that Continue to Separate Us: Borders in Our 'Borderless' World. Progress in Human Geography 30 (2): 143-161.

Paasi, Anssi. 2005a. Generations and the 'Development' of Border Studies. Geopolitics 10 (4): 663-71.

Paasi, Anssi. 2005b. The Changing Discourses on Political Boundaries: Mapping the Backgrounds, Contexts and Contents. In B/ordering Space, eds. H. v. Houtum, O. Kramsch and W. Zierhofer, 17-31. Aldershot: Ashgate.

Pisani, Michael J., Juan C. Reyes, and Baldomero G. García. 2009. Looking Back Twenty-Three Years: An Analysis of Contributors and Contributions to the Journal of Borderlands Studies, 1986 (volume 1, number 1) to 2008 (volume 23, number 2). Journal of Borderlands Studies 24 (1): 1-16.

Pratt, Mary Louise. 1992. Imperial Eyes: Travel Writing and Transculturation. London: Routledge.

Robinson, Richard. 2007. Narratives of the European Border: A History of Nowhere. Basingstoke: Palgrave Macmillian.

Said, Edward W. 1991. Orientalism: Western Conceptions of the Orient. Harmondsworth: Penguin.

Schimanski, Johan. 1996. A Poetics of the Border: Nation and Genre in Wythnos yng Nghymru Fydd and Other Texts by Islwyn Ffowc Elis. Dr. art. dissertation, Oslo.

Schimanski, Johan. 2001. Den litterære grensen: Knut Hamsuns "Dronningen af Saba". In Att forska om gränser, ed. J. L. Ramírez, 141-70. Stockholm: Nordregio.

Schimanski, Johan. 2003. Genre Borders in a Border Novel: Nadine Gordimer's My Son's Story. In Genrer och genreproblem: Teoretiska och historiska perspektiv / Genres and Their Problems: Theoretical and Historical Perspectives, eds. B. Agrell and I. Nilsson, 505-13. Göteborg: Daidalos.

Schimanski, Johan. 2006. Crossing and Reading: Notes towards a Theory and a Method. Nordlit (19): 41-63.

Schimanski, Johan, and Stephen Wolfe. 2007. Imperial Tides: A Border Poetic Reading of Heart of Darkness. In Border Poetics De-limited, eds. J. Schimanski and S. Wolfe, 217-34. Hannover: Wehrhahn.

Schimanski, Johan, and Stephen Wolfe. 2009. The ABS-Europe Biennale Kirkenes Conference Report: Cultural Production and Negotiation of Borders. $\mathrm{La}$ Frontera: Association for Borderlands Studies Newsletter 29 (2): 10-14.

Sidaway, James D. 2005. The Poetry of Boundaries: Reflections from the Portuguese-Spanish Borderlands. In B/ordering Space, eds. H. v. Houtum, O. Kramsch and W. Zierhofer, 196-206. Aldershot: Ashgate.

Simmel, Georg. 1997. The Sociology of Space. In Simmel on Culture: Selected Writings, eds. D. Frisby and M. Featherstone, 137-70. London: Sage.

Soja, Edward. 1989. Postmodern Geographies: The Reassertion of Space in Critical Social Theory. London: Verso.

Strüver, Anke. 2003. Presenting Representations: On the Analysis of Narratives and Images along the Dutch-German Border. In Routing Borders between Territories, Discourses and Practices, eds. E. Berg and H. v. Houtum, 161-76. 
Aldershot: Ashgate.

Strüver, Anke. 2005. Bor(der)ing Stories: Spaces of Absence along the DutchGerman Border. In B/ordering Space, eds. H. v. Houtum, O. Kramsch and W. Zierhofer, 207-21. Aldershot: Ashgate.

Tygstrup, Frederick. 2000. På sporet af virkeligheden. København: Gyldendal.

Vest Hansen, Malene. 2007. Public Places - Private Spaces: Site-specific Blurring of Boundaries in Sophie Calle's Jerusalem Projects. In Border Poetics Delimited, eds. J. Schimanski andS. Wolfe. Hannover: Wehrhahn.

Viken, Arvid, Brynhild Granås, and Toril Nyseth. 2008. Kirkenes: An Industrial Site Reinvented as a Border Town. Acta Borealia 25 (1): 22-44.

Viljoen, Hein, and Chris N. van der Merwe. 2007. Introduction: The Poetics of Liminality and Hybridity. Beyond the Threshold: Explorations of Liminality in Literature, eds. H. Viljoen andC. N. v. d. Merwe. New York: P. Lang.

Virilio, Paul. 1986. Speed and Politics: An Essay on Dromology. Trans. M. Polizzotti. New York: Semiotext(e).

Warnke, Martin. 1994. Political Landscape: The Art History of Nature. Trans. D. McLintock. London: Reaktion Books.

Williams, John. 2006. The Ethics of Territorial Borders: Drawing Lines in the Shifting Sand. Houndmills, Basingstoke: Palgrave.

Williams, Raymond. 1976. Keywords: A Vocabulary of Culture and Society. New York: Oxford Univ. Press.

Wolfe, Stephen. 2006. Reanimating the Dead: Suggestions Toward the Analysis of a Brontë Border Narrative. Nordlit (19): 87-98. 